\title{
Inhibitory effect of NVP-BKM120 on cholangiocarcinoma cell growth
}

\author{
SUREERAT PADTHAISONG ${ }^{1,2}$, HASAYA DOKDUANG ${ }^{1-3}$, SUPAK YOTHAISONG $^{1,2}$, \\ ANCHALEE TECHASEN ${ }^{2,4}$, NISANA NAMWAT ${ }^{1-3}$, PUANGRAT YONGVANIT ${ }^{1-3}$, NARONG KHUNTIKEO ${ }^{2,3,5}$, \\ ATTAPOL TITAPUN ${ }^{2,5}$, SAKKARN SANGKHAMANON ${ }^{2,3,6}$ and WATCHARIN LOILOME ${ }^{1,5,6}$ \\ ${ }^{1}$ Department of Biochemistry; ${ }^{2}$ Cholangiocarcinoma Research Institute (CARI), \\ Faculty of Medicine, Khon Kaen University; ${ }^{3}$ Cholangiocarcinoma Screening and Care Program (CASCAP); \\ ${ }^{4}$ Faculty of Associated Medical Sciences, Khon Kaen University; Departments of ${ }^{5}$ Surgery and \\ ${ }^{6}$ Pathology, Faculty of Medicine, Khon Kaen University, Khon Kaen 40002, Thailand
}

Received July 28, 2016; Accepted January 25, 2018

DOI: $10.3892 / \mathrm{ol} .2018 .8848$

\begin{abstract}
Abnormal activation of the phosphatidylinositol 3-kinase (PI3K) pathway has been demonstrated in certain types of cancer, including cholangiocarcinoma (CCA). This pathway may therefore be a promising target for CCA treatment. The present study assessed the inhibitory effect of NVP-BKM120, a pan-class I PI3K inhibitor, on CCA cell growth. This inhibitory effect was determined using CCA cell lines and in CCA-inoculated mice. The result from sulforhodamine B (SRB) assay demonstrated that NVP-BKM120 treatment inhibited CCA cell growth in a dose-dependent manner, even at the lowest tested concentration. The in vivo study revealed that oral administration of NVP-BKM120 (10 or $30 \mathrm{mg} / \mathrm{kg}$ ) to CCA-inoculated nude mice led to a reduction in tumor growth when compared with controls, which was indicated by an immunohistochemical assay for Ki67 expression. In addition, the result from TUNEL assay demonstrated that NVP-BKM120 induced cancer cell death without any signs of toxicity, which indicated by the body weight of mice (data not shown). Western blot analysis demonstrated that NVP-BKM120 inhibited CCA cell growth by suppressing $\mathrm{RAC}$ serine/threonine protein kinase/mechanistic target of rapamycin activation and inhibiting the phosphorylation of phosphatase and tensin homolog, which is the inactivation form of the negative regulator of this pathway. Therefore, the results of the present study indicated that NVP-BKM120 should be considered as a therapeutic agent against CCA that could be used to improve treatment.
\end{abstract}

Correspondence to: Dr Watcharin Loilome, Department of Biochemistry, Faculty of Medicine, Khon Kaen University, 123 Mittraparp Road, Muang, Khon Kaen 40002, Thailand E-mail:watloi@yahoo.com

Key words: cholangiocarcinoma, Opisthorchis viverrini, phosphatidylinositol 3-kinase pathway, NVP-BKM120

\section{Introduction}

Cholangiocarcinoma (CCA) is a malignant tumor of the bile duct epithelium. The incidence of CCA is highest in northeast Thailand, where the liver fluke (Opisthorchis viverrini, hereafter Ov) infection rate is high (1). The association between Ov infection and CCA is well established in this region $(2,3)$ and $\mathrm{Ov}$ infection is defined as a major risk factor for CCA (4).

The majority of patients with CCA have a poor prognosis as early stage CCA being difficult to diagnose and the onset of symptoms only occurring in advanced stages, causing patients to seek treatment in later stages of disease (5). Surgical resection is curative only for patients that present at an early stage, not for those at late or advanced stages $(6,7)$. Therefore, novel approaches, particularly those involving targeted therapy, are urgently required.

Multiple protein kinases are activated in CCA tissues and cell lines; these include protein kinases of the phosphatidylinositol 3-kinase (PI3K)/RAC serine/threonine-protein kinase (Akt) pathway (8). The PI3K/Akt signaling pathway serves an important role in a number of cellular processes, including cell growth, the cell cycle and programmed cell death $(9,10)$. The activation of this pathway is thus involved in the progression of various types of cancer, including CCA (9-13). Therefore, targeting the PI3K/Akt pathway may be beneficial for CCA therapy.

Buparlisib or NVP-BKM120 is a highly selective pan-class I PI3K inhibitor (14). The ability of NVP-BKM120 to induce apoptosis or exert anti-proliferative effects via the $\mathrm{PI} 3 \mathrm{~K} / \mathrm{Akt} / \mathrm{mechanistic} \mathrm{target} \mathrm{of} \mathrm{rapamycin} \mathrm{(mTOR)} \mathrm{pathway}$ has been demonstrated in various types of cancer (15-18). In acute myeloid leukemia, NVP-BKM120 has been demonstrated to induce cell growth arrest and apoptosis by inhibiting this signaling pathway (15). In addition, the antitumor activity of NVP-BKM120 has also been demonstrated in bone and soft tissue sarcoma, multiple myeloma and glioma (16-18). Increased $\mathrm{PI} 3 \mathrm{~K} / \mathrm{Akt} / \mathrm{mTOR}$ activation has been revealed in multiple types of cancer, including CCA $(8,10,19,20)$; NVP-BKM120 may thus possess the potential to inhibit the progression of cancer. Therefore, the present study aimed 
to evaluate the inhibitory effect of NVP-BKM120 on CCA progression and to assess the molecular mechanism by which NVP-BKM120 suppresses the development of CCA.

\section{Materials and methods}

Cell lines and cell culture. The human CCA M213, KKU100, M055, M139 and OCA17 cell lines, were established by Dr Banchop Sripa at the Cholangiocarcinoma Research Institute (CARI), Khon Kaen University (Khon Kaen, Thailand) (21). Cell lines were cultured in Ham's F-12 medium (Gibco; Thermo Fisher Scientific, Inc., Waltham, MA, USA) supplemented with $2 \mathrm{mg} / \mathrm{ml}$ sodium bicarbonate, $10 \%$ fetal bovine serum (Gibco; Thermo Fisher Scientific, Inc.), $100 \mathrm{U} / \mathrm{ml}$ penicillin and $100 \mu \mathrm{g} / \mathrm{ml}$ streptomycin in a humidified atmosphere at $37^{\circ} \mathrm{C}$ which contained $5 \% \mathrm{CO}_{2}$.

Antibodies and reagents. The antibodies used in the present study were as follows: Rabbit polyclonal anti-Ki67 antibodies (1:300, cat. no. ab15580; Abcam, Cambridge, UK), rabbit monoclonal anti-Akt antibodies (1:500, cat. no. ab32505; Abcam), rabbit polyclonal anti-phospho-phosphatase and tensin homolog (PTEN; Ser380) antibodies (1:500, cat. no. ab47332; Abcam), rabbit polyclonal anti-phospho-Akt (Ser473) antibodies (1:1,000, cat. no. 9271; Cell Signaling Technology, Inc., Danvers, MA, USA), rabbit monoclonal anti-mTOR antibodies (1:1,000, cat. no. 2983; Cell Signaling Technology, Inc.), rabbit polyclonal anti-phospho-mTOR (Ser2448) antibodies (1:1,000, cat. no. 2971; Cell Signaling Technology, Inc.), rabbit polyclonal anti-B-cell lymphoma-2 (Bcl-2) antibodies (1:1,000, cat. no. 2876; Cell Signaling Technology, Inc.), mouse monoclonal anti-Bcl-2 associated protein $\mathrm{X}$ (Bax) antibodies $(1: 1,000$, cat. no. 610983; BD Biosciences, Franklin Lakes, NJ, USA) and mouse monoclonal anti- $\beta$-actin antibodies $(1: 10,000$, cat. no. 5541; Sigma-Aldrich, Merck KGaA, Darmstadt, Germany). NVP-BKM120 was purchased from Active Biochem Ltd. (Hong Kong, China).

Growth inhibition assay. The growth inhibitory effect of NVP-BKM120 was determined using a sulforhodamine B (SRB) assay. CCA cells $\left(5 \times 10^{3}\right.$ cells in $100 \mu 1 \mathrm{Ham}$ 's F-12 medium) (Gibco; Thermo Fisher Scientific, Inc.) were seeded in 96 -well plates and incubated overnight at $37^{\circ} \mathrm{C}$ and $5 \% \mathrm{CO}_{2}$. The cells were then treated with NVP-BKM120 in various concentrations, including $1,10,100,1,000$, 10,000 and $100,000 \mathrm{nM}$, and incubated for $48 \mathrm{~h}$. Following this, cells were fixed with $10 \%$ cold trichloroacetic acid for $1 \mathrm{~h}$ at $4^{\circ} \mathrm{C}$ and stained with $0.4 \%$ w/v SRB in $1 \%$ v/v acetic acid for $30 \mathrm{~min}$ at room temperature. Excess dye was washed with $1 \%$ acetic acid and stained cells were solubilized with $200 \mu \mathrm{l}$ of $10 \mathrm{mM}$ unbuffered Tris-base. The absorbance was measured using a microplate reader (Sunrise; Tecan Group Ltd., Maanedorf, Switzerland) at $540 \mathrm{~nm}$. The percentage of growth inhibition (\% GI) in three independent experiments was calculated using the formula, $\% \mathrm{GI}=1-(\mathrm{Nt} / \mathrm{Nc}) \times 100$. Nt and Nc refer to the absorbance of the treated and control groups, respectively. The half-maximal inhibitory concentration $\left(\mathrm{IC}_{50}\right)$ was evaluated using interpolation from dose-response curves, as described previously (22).
Animal study. The six-week-old, female athymic BALB/c nude mice (3 mice/group) weight range $18-20 \mathrm{~g}$ were purchased from the National Animal Laboratory (Mahidol University, Nakhon Pathom, Thailand). Mice were housed under pathogen-free conditions and given ad libitum access to food and water in a temperature-controlled room of $23 \pm 2^{\circ} \mathrm{C}$, with a $12 / 12 \mathrm{~h}$ light/dark cycle, $10-15$ air changes/h, room humidity of 30-60\% and light levels 350-400 lux at the Animal Center, Faculty of Medicine, Khon Kaen University. Mice were injected subcutaneously with $3 \times 10^{6}$ cells of the M213 CCA cell line. When a tumor became visible, mice were divided into three groups. The control group was orally administrated with the vehicle (NMP-PEG3000; Sigma-Aldrich, Merck $\mathrm{KGaA}$ ), whilst the treatment groups received 10 or $30 \mathrm{mg} / \mathrm{kg}$ of NVP-BKM120 orally for 14 days. Body weight and tumor volume (tumor volume $=0.5 \mathrm{x}$ width ${ }^{2} \mathrm{x}$ length) were determined twice a week. Relative tumor volume was calculated by using the formula: Relative tumor volume=tumor volume day $\mathrm{x} /$ tumor volume day 0 ). After three weeks of the experiment, the mice were anesthetized with $2 \%$ isoflurane and cervical dislocation was used for euthanasia. The tumor and organs collected for further experimentation. All experiments were approved by the Animal Ethics Committee of the Khon Kaen University (NELAC22/2557).

Immunohistochemical assay for Ki67. Nude mice tumor tissues were fixed in $10 \%$ buffered formaldehyde at room temperature for a week, embedded in paraffin blocks and then sectioned at a thickness of $4 \mu \mathrm{m}$. Ki67 Immunostaining was performed to determine cell proliferation using tissue sections. Tissue sections were deparaffinized and rehydrated with xylene and an ethanol series. The antigen was then retrieved with Tris-EDTA buffer (pH 9) using a pressure cooker at $120^{\circ} \mathrm{C}$ for 3 min. Endogenous enzymes and non-specific bonding were blocked using $0.3 \%$ hydrogen peroxide and $10 \%$ skimmed milk with 30 min agitation at room temperature, respectively. Anti-Ki67 antibodies were incubated at room temperature for $1 \mathrm{~h}$ followed by a further incubation at $4^{\circ} \mathrm{C}$ overnight in a moisture chamber. The sections were then incubated with secondary antibodies conjugated to horseradish peroxidase (Envision; Dako; Agilent Technologies, Inc., Santa Clara, CA, USA) at room temperature for $1 \mathrm{~h}$ and the signal was developed using $0.1 \%$ diaminobenzidine tetrahydrochloride for $5 \mathrm{~min}$. Sections were counterstained with hematoxylin at room temperature for $2 \mathrm{~min}$ and dehydrated using an ethanol series followed by xylene prior to mounting. Sections were observed using a light microscope (Nikon Eclipse Ni-U; Nikon, Tokyo, Japan). Ki67 positive cells in each tumor section were counted in at least five fields of view at a magnification of $\times 400$ (NIS-Elements version 4.0; Nikon, Tokyo, Japan) and the percentage of Ki67 positive cells were calculated.

In situ terminal deoxynucleotidyl transferase dUTP nick-end labeling (TUNEL) assay for apoptosis. A TUNEL assay was performed to detected DNA fragments in apoptotic cells. The TUNEL assay was performed using paraffin-embedded tumor tissue from nude mice using the in situ Cell Death Detection kit, POD (cat. no. 11684817 910; Roche, Mannheim, Germany). Briefly, nude mice tumor tissues were fixed in $10 \%$ buffered formaldehyde at room temperature for a week, embedded in 
paraffin blocks and then sectioned at a thickness of $4 \mu \mathrm{m}$. Tissue sections were deparaffinized and rehydrated with xylene and an ethanol series (100, 90, 80 and 70\% ethanol) and treated with $20 \mu \mathrm{g} / \mathrm{ml}$ proteinase $\mathrm{K}$ at $37^{\circ} \mathrm{C}$ for $30 \mathrm{~min}$. TUNEL reaction mixture was added $50 \mu \mathrm{l} /$ section, incubate at $37^{\circ} \mathrm{C}$ for $1 \mathrm{~h}$. Converter-POD (anti-fluorescein antibody conjugated with horseradish peroxidase) was added $50 \mu \mathrm{l} /$ section. Tissue sections were incubated at $37^{\circ} \mathrm{C}$ for $30 \mathrm{~min}$ and the signal was developed using $0.1 \%$ diaminobenzidine tetrahydrochloride for $5 \mathrm{~min}$. Tissue sections were dehydrated prior to mounting (Bio Optica Milano SpA, Milan, Italy). The percentage of TUNEL-positive cells was determined using the light microscope from at least five fields of view at a magnification of x400 (NIS-Elements version 4.0; Nikon).

Western blot analysis. Total protein was extracted from $50 \mathrm{mg}$ of frozen nude mouse tumor tissue, stored at $-80^{\circ} \mathrm{C}$. Tumor tissues were lysed in $200 \mu 1$ radioimmunoprecipitation assay lysis buffer (150 mM NaCl, 0.5 M Tris-HCl pH 7.4, 1\% Tween-20, $1 \%$ sodium deoxycholate and $0.1 \%$ SDS) for $10 \mathrm{~min}$ on ice. then homogenized using a grinder. Whole lysates were then centrifuged at a speed of $14,000 \mathrm{~g}$ at $4^{\circ} \mathrm{C}$ for $5 \mathrm{~min}$ and the supernatant was collected and stored at $-80^{\circ} \mathrm{C}$ until further use. Protein concentration was determined using a bicinchoninic acid protein assay kit (Thermo Fisher Scientific, Inc.). Protein extract were solubilized in $4 \mathrm{X}$ SDS buffer (1 M Tris-HCL pH 6.8, SDS, glycerol, $\beta$-mercaptoethanol, bromophenol blue) containing dithiothreitol and boiled at $95^{\circ} \mathrm{C}$ for $5 \mathrm{~min}$. Protein was loaded ( $30 \mu \mathrm{g} /$ well) and separated by SDS-PAGE (10\% gel) and then transferred to a polyvinylidene difluoride membrane (EMD Millipore, Billerica, MA, USA). The membrane was blocked using $10 \%$ skimmed milk in TBS overnight at $4^{\circ} \mathrm{C}$, then incubated with antibodies against Bax, Bcl-2, p-Akt, Akt, p-mTOR, mTOR, p-PTEN and $\beta$-actin at room temperature for $1 \mathrm{~h}$. The membrane was then rinsed using TBS containing $0.1 \%$ polyoxyethylenesorbitan monolaurate (TTBS) and incubated with secondary antibodies conjugated to horseradish peroxidase (Santa Cruz Biotechnology, Inc., Dallas, TX, USA) at room temperature for $1 \mathrm{~h}$ prior to rinsing with TTBS followed by TBS. The signal was developed using an ECL Prime Western Blotting Detection system using ImageQuant ${ }^{\mathrm{TM}}$ LAS 4000 Control Software (GE Healthcare, Chicago, IL, USA). Human $\beta$-actin was used as a loading control.

Statistical analysis. The results of the growth inhibition assay, Ki67 staining, apoptosis assay and relative tumor volume of nude mice are represented as the mean \pm standard deviation. Statistical comparisons between two groups of Ki67 staining and apoptosis assay was determined using unpaired Student's t-test. The relative tumor volume of mice from different groups was analyzed using two-way analysis of variance followed with the Bonferroni method. Statistical analysis was performed using GraphPad Prism 5 (GraphPad Software, Inc., La Jolla, CA, USA). $\mathrm{P}<0.05$ was considered to indicate a statistically significant result.

\section{Results}

Growth inhibitory effect of NVP-BKM120 on CCA cell lines and CCA-inoculated nude mice. NVP-BKM120 inhibits CCA cell growth in a dose-dependent manner (Fig. 1), with the

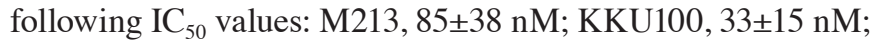

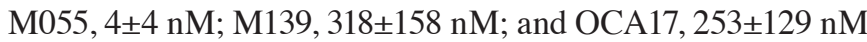
(Table I). Furthermore, NVP-BKM120 at concentrations of 10 and $30 \mathrm{mg} / \mathrm{kg}$ significantly suppressed tumor growth when compared with the control on days 14 and 12 , respectively ( $\mathrm{P}<0.01$; Fig. 2).

NVP-BKM120 inhibits cancer cell proliferation and induces apoptosis in the CCA mouse model. As demonstrated in vitro, NVP-BKM120 inhibits CCA cell growth. Therefore, the effect of NVP-BKM120 on the mouse model was assessed. An immunohistochemical assay was performed to detect the Ki67 proliferation marker in the paraffin-embedded tumor tissues of nude mice. The percentage of Ki67 nuclear staining in the tumor cells of $30 \mathrm{mg} / \mathrm{kg}$ NVP-BKM120 treated mice was significantly decreased when compared with the control mice $(\mathrm{P}<0.05$; Fig. 3A and $\mathrm{B})$. In addition, NVP-BKM120 treatment caused a significant increase in the percentage of apoptotic cells in treatment groups when compared with those in the control groups $(10 \mathrm{mg} / \mathrm{kg}, \mathrm{P}<0.001 ; 30 \mathrm{mg} / \mathrm{kg}, \mathrm{P}<0.01$; Fig. 3C and D). Western blot analysis demonstrated that NVP-BKM120 induced the expression of the pro-apoptotic protein Bax, whereas the expression of $\mathrm{Bcl}-2$, which is anti-apoptotic, was decreased (Fig. 3E and F).

Molecular mechanisms by which NVP-BKM120 suppresses $C C A$ cell growth. The present study also assessed the molecular mechanism by which NVP-BKM120 suppressed CCA cell growth via the PI3K/Akt pathway using a western blot assay. The results indicated that NVP-BKM120 inhibits Akt and mTOR phosphorylation in a dose-dependent manner. In addition, the drug also inhibits the phosphorylation of PTEN, which is a negative regulator of the PI3K/Akt/mTOR pathway (Fig. 4).

\section{Discussion}

$\mathrm{PI} 3 \mathrm{~K} / \mathrm{Akt} / \mathrm{mTOR}$ is a signaling pathway that serves a notable role in various cellular processes, including growth, the cell cycle and cell survival (23-25). Previous studies have implicated this pathway in the progression of certain types of cancer that are associated with poor patient outcome (20,26-28). A previous study observed an increase in PI3K/Akt/mTOR pathway activation in CCA tissue and cell lines (8). Additionally, Yothaisong et al (10) demonstrated that the increased activation of this pathway was associated with CCA metastasis. Therefore, targeting the PI3K/Akt/mTOR pathway in the treatment of patients with CCA may be a beneficial approach.

Buparlisib or NVP-BKM120 is a highly selective pan-class I PI3K inhibitor. It specifically blocks PI3K with a specificity at least 50-fold higher than for other protein kinases (14). The effect of NVP-BKM120 on the inhibition of tumor growth and apoptosis induction has been demonstrated in various types of cancer. It has been revealed to inhibit cell growth, induce apoptosis and reduce the number and size of colonies in bone and soft tissue sarcomas (16). Koul et al (29) revealed that NVP-BKM120 treatment inhibits glioma cell proliferation. In addition, Martin et al (17) demonstrated that NVP-BKM120 treatment inhibited the growth of multiple myeloma cells, and 


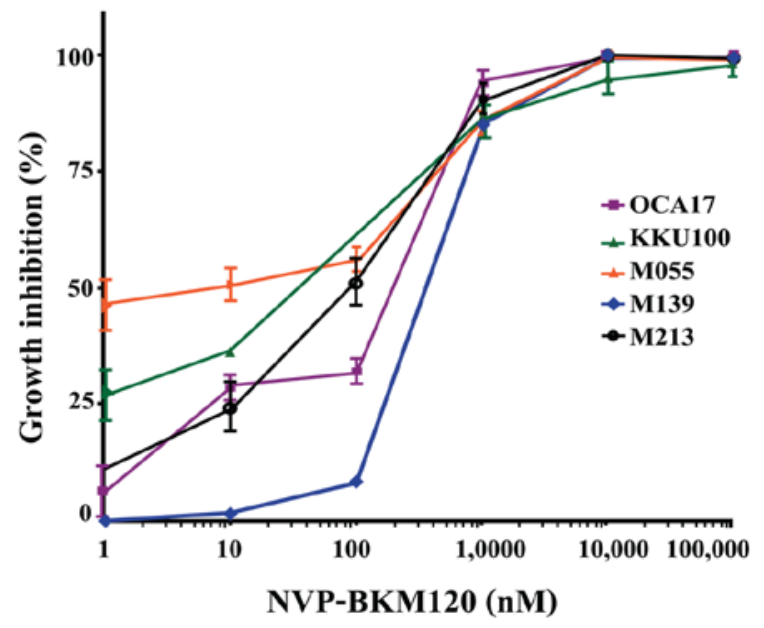

Figure 1. Growth inhibition effect of NVP-BKM120 on CCA cell lines. The CCA M213, KKU100, M055, M139 and OCA17 cell lines were exposed to 1-10 $\mathrm{nM}$ NVP-BKM120. Following $48 \mathrm{~h}$, cell proliferation was detected using the sulforonamide B assay. Values of percent cell growth inhibition are expressed as the mean \pm standard deviation of three independent experiments. CCA, cholangiocarcinoma.
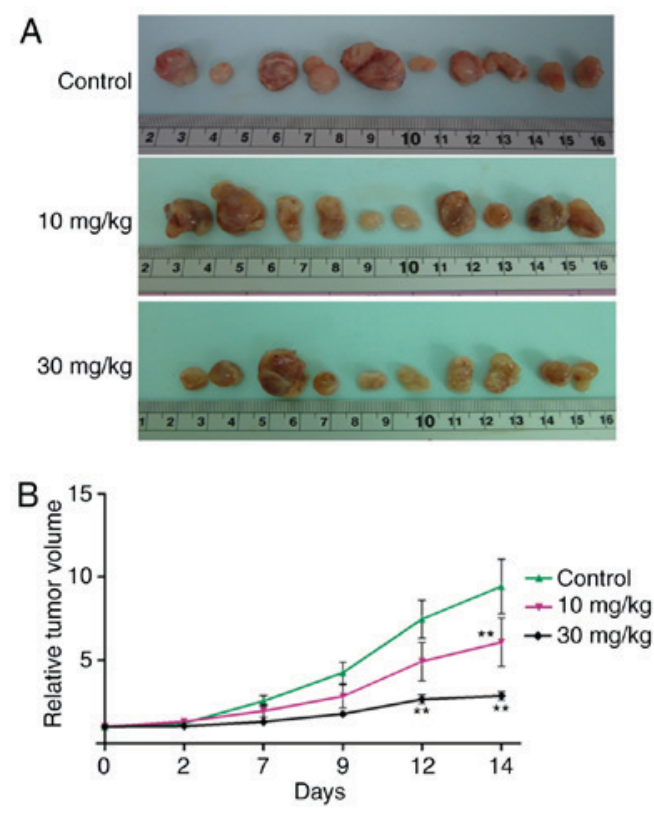

Figure 2. Antitumor activity of NVP-BKM120 in CCA inoculated nude mice (3 mice in each group). (A) Representative images of the M213 CCA cell line-implanted tumors in mice after 21 days of experiment. Mice were orally administered 10 or $30 \mathrm{mg} / \mathrm{kg}$ of NVP-BKM120 for 14 days. (B) Tumor growth in mice that received 10 or $30 \mathrm{mg} / \mathrm{kg} \mathrm{NVP-BKM120}$ orally for 14 days was significantly decreased when compared with control mice. Data in (B) are expressed as the mean \pm standard deviation (3 mice in each group) using two-way analysis of variance. ${ }^{* *} \mathrm{P}<0.01$ vs. the control. CCA, cholangiocarcinoma

the antitumor effect of NVP-BKM120 was also detected in breast cancer (30). Therefore, the current study investigated the inhibitory effect of NVP-BKM120 on CCA cells and evaluated its potential use in CCA therapy.

The present study demonstrated that NVP-BKM120 treatment inhibited CCA cell growth in a dose-dependent manner at nanomolar concentrations. However, the $\mathrm{IC}_{50}$ levels of NVP-BKM120 in glioma, breast cancer and lung
Table I. Growth inhibitory effect of NVP-BKM120 on CCA cell lines.

\begin{tabular}{lc} 
CCA cell line & $\mathrm{IC}_{50}$ of NVP-BKM \\
\hline M213 & $85 \pm 38$ \\
KKU100 & $33 \pm 15$ \\
M055 & $4 \pm 4$ \\
M139 & $318 \pm 158$ \\
OCA17 & $253 \pm 129$
\end{tabular}

Data presented as the mean \pm standard deviation. $\mathrm{IC}_{50}$, half-maximal inhibitory concentration; CCA, cholangiocarcinoma.

adenocarcinoma exhibited the same effects at micromolar ranges (29-31).

The present study assessed the effect of NVP-BKM120 on CCA development using the CCA-inoculated nude mouse model. The oral administration of NVP-BKM120 at 10 and $30 \mathrm{mg} / \mathrm{kg}$ concentrations significantly inhibited CCA cell growth when compared with controls. This is consistent with the results of previous studies, which demonstrated the growth inhibitory effect of NVP-BKM120 in breast cancer and glioblastoma $(32,33)$. NVP-BKM120 also exhibited minimal or no toxic effects in normal cells (34). The growth inhibitory effect of NVP-BKM120 is indicated by immunostaining for the proliferation marker Ki67. The results of the present study indicated that the percentage of Ki67-positive nuclear-stained cells in tumor tissues of the $30 \mathrm{mg} / \mathrm{kg}$ NVP-BKM120-treated group was significantly lower than that of control group, similar to a previous result reported in colorectal cancer (35). The effect of NVP-BKM120 treatment on apoptosis using a TUNEL assay was then assessed. The number of apoptotic cells was significantly increased in the tumor tissue of mice treated with 10 or $30 \mathrm{mg} / \mathrm{kg}$ NVP-BKM120 when compared with tissue from control animals. Furthermore, there was an increase in expression of the pro-apoptotic protein $\mathrm{Bax}$ and a reduction in that of the anti-apoptotic protein Bcl-2 in NVP-BKM120-treated mice. These results indicated that NVP-BKM120 treatment inhibited CCA progression via the induction of apoptosis, which reflect the results of a previous study into acute lymphoblastic leukemia (36).

There is considerable evidence to indicate that increased activation of the PI3K/Akt signaling pathway can be induced by various mechanisms, including mutation of PI3K or Akt, constitutive activation of an upstream regulator, the loss of PTEN expression and an increased expression of phospho-PTEN, which is the inactive form $(10,37)$. In addition, the results of the present study revealed that increased activation of the PI3K/Akt signaling pathway in CCA is primarily caused by, loss of function of the negative regulator PTEN function via loss of expression, increased phosphorylation and increased expression of the pathway components (10). Thus, the molecular mechanism by which NVP-BKM120 inhibits CCA development was assessed. The current study analyzed the expression and phosphorylation of Akt, mTOR and PTEN, which are over expressed in CCA and involved in tumor 

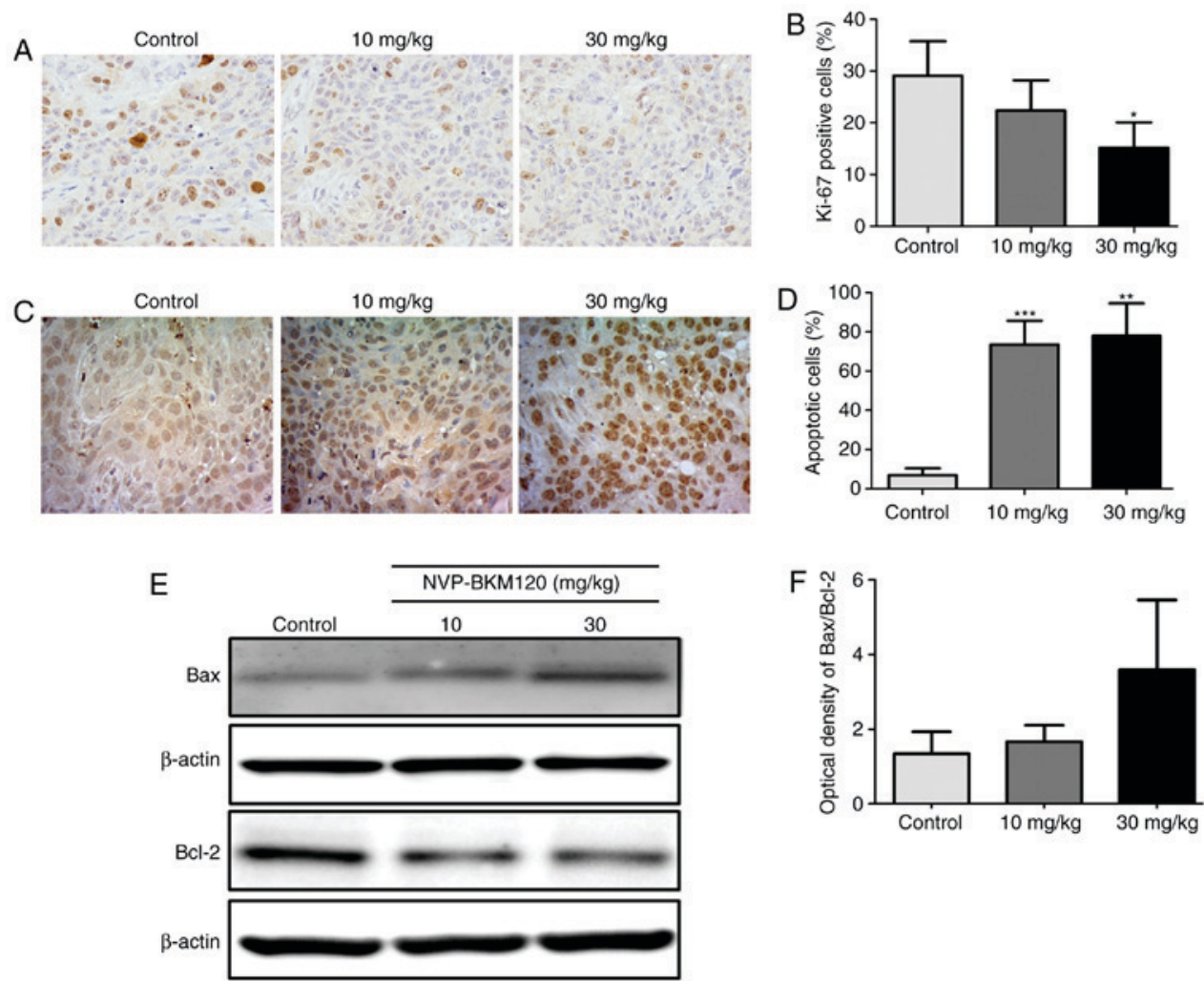

Figure 3. NVP-BKM120 inhibits cancer cell proliferation and induces apoptosis in a CCA mouse model. (A) Proliferative cells in nude mouse tumor tissue sections were determined using Ki67 immunostaining (magnification, $\mathrm{x} 400$ ). (B) The percentage of proliferative cells were significantly reduced in mice treated with $30 \mathrm{mg} / \mathrm{kg}$ NVP-BKM120 when compared with controls. (C) Apoptotic cells were detected using a in situ terminal deoxynucleotidyl transferase dUTP nick end labeling assay (magnification, x400). (D) NVP-BKM120 treatment significantly induced cell death in a dose-dependent manner when compared with the control group. (E) Western blot analysis demonstrated an increase in the expression of the pro-apoptotic protein, Bax, whereas that of the anti-apoptotic protein Bcl-2, was decreased. (F) Protein expression ratio of Bax/Bcl-2. Data in (B) and (D) are presented as the mean \pm standard deviation (3 mice in each group) analyzed using a Student's t-test for independent samples. Data in $(\mathrm{F})$ are presented as the mean \pm standard deviation of protein band intensity, which was normalized with $\beta$-actin. ${ }^{*} \mathrm{P}<0.05,{ }^{* *} \mathrm{P}<0.01,{ }^{* * *} \mathrm{P}<0.001$. CCA, cholangiocarcinoma; Bax, Bcl-2 associated protein $\mathrm{X}$; Bcl-2, B-cell lymphoma-2.

cell proliferation. The results demonstrated that $30 \mathrm{mg} / \mathrm{kg}$ NVP-BKM120 treatment markedly reduced Akt phosphorylation. These are congruent to the results of a previous study of follicular lymphoma, which revealed that $30 \mathrm{mg} / \mathrm{kg}$ NVP-BKM120 treatment also reduced the phosphorylation of Akt (38). Furthermore, these results are similar to a study concerning acute lymphoblastic leukemia, which demonstrated that NVP-BKM120 (at 1, 10 and $50 \mu \mathrm{M}$ ) inhibits the phosphorylation of Akt and mTOR in a dose-dependent manner (36). In addition, the present study also revealed a decrease in phospho-PTEN in the tumor tissues of NVP-BKM120-treated mice. These results revealed that NVP-BKM120 inhibits CCA cell growth via the inhibition of Akt, mTOR and PTEN phosphorylation.

In conclusion, the present study revealed that NVP-BKM120 exhibited antitumor activity against CCA, inhibiting of CCA cell growth at nanomolar concentrations. NVP-BKM120 suppressed CCA growth and induce apoptosis in CCA-inoculated mice without toxicity (data not shown). The current study also revealed that NVP-BKM120 exerted an anticancer effect by blocking Akt, mTOR and PTEN activation. These results indicated that targeting the $\mathrm{PI} 3 \mathrm{~K} / \mathrm{Akt} / \mathrm{mTOR}$ signaling pathway with NVP-BKM120 led to the suppression of CCA cell growth and the induction of cell death. The present study thus provides data necessary for the development of NVP-BKM120 treatment for

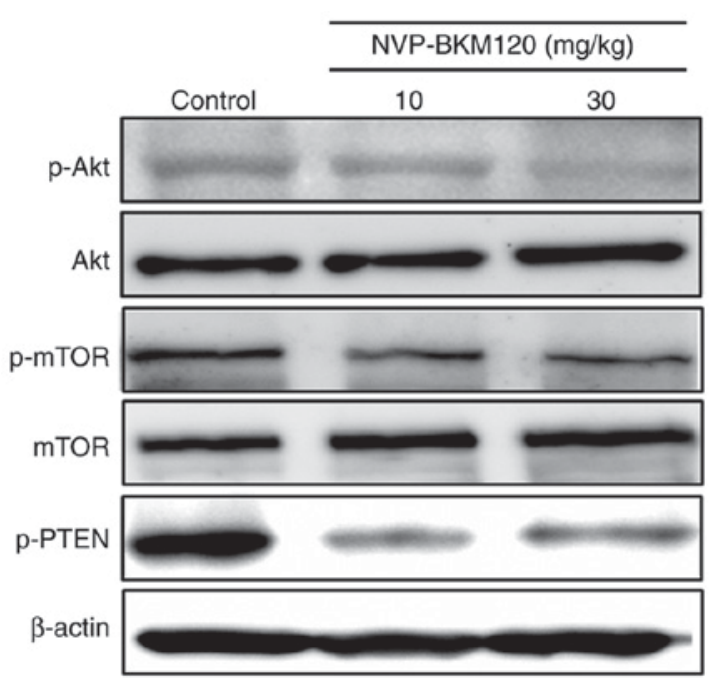

Figure 4. Molecular mechanisms by which NVP-BKM120 suppresses CCA cell growth. Western blot analysis revealed a decrease in p-Akt, p-mTOR and p-PTEN expression in protein extracted from the tumor tissue of NVP-BKM120 treated mice. CCA, cholangiocarcinoma; p-Akt, phosphorylated RAC serine/threonine-protein kinase; mTOR, mechanistic target of rapamycin; PTEN, phosphatase and tensin homolog.

CCA alone or in combination with conventional chemotherapeutic drugs. 


\section{Acknowledgements}

The authors would like to thank Professor Trevor N. Petney for help with editing the manuscript.

\section{Funding}

The present study was supported by the Thailand Research Fund a Research Assistantship Grant of the Faculty of Medicine, Khon Kaen University (grant no. AS59204), Khon Kaen University grant (grant no. KKU61) and grants from the Higher Education Research Promotion and National Research University Project of Thailand, Office of the Higher Education Commission, through the Center of Excellence in Specific Health Problems in Greater Mekong Sub-region cluster (SHeP-GMS), Khon Kaen University allocated to WL.

\section{Availability of data and materials}

The analyzed datasets generated during the present study are available from the corresponding author on reasonable request.

\section{Authors' contributions}

SP designed the experiments, performed the experiments, analyzed the data, written the manuscript, prepared figures and tables and reviewed drafts of the manuscript. HD and SY designed the experiments, performed the experiments, analyzed the data and prepared figures and tables. ATe, NN and PY designed the experiments and provided reagents/materials/analysis tools. NK, ATi and SS reviewed the drafts of the manuscript, designed experiments and provided reagents/ materials. WL designed the experiments, analysed the data, provided reagents/materials/analysis tools and reviewed the drafts of the manuscript.

\section{Ethics approval and consent to participate}

All experiments were approved by the Animal Ethics Committee of the Khon Kaen University (NELAC22/2557; Khon Kaen, Thailand).

\section{Consent for publication}

Not applicable.

\section{Competing interests}

The authors declare that they have no competing interests.

\section{References}

1. Vatanasapt V, Sriamporn S and Vatanasapt P: Cancer control in Thailand. Jpn J Clin Oncol 32 (Suppl): S82-S91, 2002.

2. Parkin DM, Ohshima H, Srivatanakul P and Vatanasapt V: Cholangiocarcinoma: Epidemiology, mechanisms of carcinogenesis and prevention. Cancer Epidemiol Biomarkers Prev 2: 537-544, 1993.

3. Thamavit W, Bhamarapravati N, Sahaphong S, Vajrasthira S and Angsubhakorn S: Effects of dimethylnitrosamine on induction of cholangiocarcinoma in Opisthorchis viverrini-infected Syrian golden hamsters. Cancer Res 38: 4634-4639, 1978.

4. Sripa B and Pairojkul C: Cholangiocarcinoma: Lessons from Thailand. Curr Opin Gastroenterol 24: 349-356, 2008.
5. Banales JM, Cardinale V, Carpino G, Marzioni M, Andersen JB, Invernizzi P, Lind GE, Folseraas T, Forbes SJ, Fouassier L, et al: Expert consensus document: Cholangiocarcinoma: Current knowledge and future perspectives consensus statement from the European Network for the Study of Cholangiocarcinoma) ENS-CCA). Nat Rev Gastroenterol Hepatol 13: 261-280, 2016.

6. Blechacz B and Gores GJ: Cholangiocarcinoma: Advances in pathogenesis, diagnosis, and treatment. Hepatology 48: 308-321, 2008.

7. Khan SA, Thomas HC, Davidson BR and Taylor-Robinson SD: Cholangiocarcinoma. Lancet 366: 1303-1314, 2005.

8. Dokduang H, Juntana S, Techasen A, Namwat N, Yongvanit P, Khuntikeo N, Riggins GJ and Loilome W: Survey of activated kinase proteins reveals potential targets for cholangiocarcinoma treatment. Tumour Biol 34: 3519-3528, 2013.

9. Fresno Vara JA, Casado E, de Castro J, Cejas P, Belda-Iniesta C and González-Barón M: PI3K/Akt signalling pathway and cancer. Cancer Treat Rev 30: 193-204, 2004.

10. Yothaisong S, Dokduang H, Techasen A, Namwat N, Yongvanit P, Bhudhisawasdi V, Puapairoj A, Riggins GJ and Loilome W: Increased activation of PI3K/AKT signaling pathway is associated with cholangiocarcinoma metastasis and PI3K/mTOR inhibition presents a possible therapeutic strategy. Tumour Biol 34: 3637-3648, 2013.

11. DeGraffenried LA, Fulcher L, Friedrichs WE, Grünwald V, Ray RB and Hidalgo M: Reduced PTEN expression in breast cancer cells confers susceptibility to inhibitors of the PI3 kinase/Akt pathway. Ann Oncol 15: 1510-1516, 2004.

12. Shaw RJ and Cantley LC: Ras, PI(3)K and mTOR signalling controls tumour cell growth. Nature 441: 424-430, 2006.

13. Shukla S, Maclennan GT, Hartman DJ, Fu P, Resnick MI and Gupta S: Activation of PI3K-Akt signaling pathway promotes prostate cancer cell invasion. Int J Cancer 121: 1424-1432, 2007.

14. Maira SM, Pecchi S, Huang A, Burger M, Knapp M, Sterker D, Schnell C, Guthy D, Nagel T, Wiesmann M, et al: Identification and characterization of NVP-BKM120, an orally available pan-class I PI3-kinase inhibitor. Mol Cancer Ther 11: 317-328, 2012.

15. Allegretti M, Ricciardi MR, Licchetta R, Mirabilii S, Orecchioni S, Reggiani F, Talarico G, Foà R, Bertolini F, Amadori S, et al: The pan-class I phosphatidyl-inositol-3 kinase inhibitor NVP-BKM120 demonstrates anti-leukemic activity in acute myeloid leukemia. Sci Rep 5: 18137, 2015.

16. Anderson JL, Park A, Akiyama R, Tap WD, Denny CT and Federman N: Evaluation of in vitro activity of the class I PI3K inhibitor Buparlisib (BKM120) in pediatric bone and soft tissue sarcomas. PLoS One 10: e0133610, 2015.

17. Martin SK, Gan ZY, Fitter S, To LB and Zannettino AC: The effect of the PI3K inhibitor BKM120 on tumour growth and osteolytic bone disease in multiple myeloma. Leuk Res 39: 380-387, 2015

18. Speranza MC, Nowicki MO, Behera P, Cho CF, Chiocca EA and Lawler SE: BKM-120 (Buparlisib): A phosphatidyl-inositol-3 kinase inhibitor with anti-invasive properties in glioblastoma. Sci Rep 6: 20189, 2016.

19. Chang KY, Tsai SY, Chen SH, Tsou HH, Yen CJ, Liu KJ, Fang HL, Wu HC, Chuang BF, Chou SW, et al: Dissecting the EGFR-PI3K-AKT pathway in oral cancer highlights the role of the EGFR variant III and its clinical relevance. J Biomed Sci 20: 43, 2013.

20. Malinowsky K, Nitsche U, Janssen KP, Bader FG, Späth C, Drecoll E, Keller G, Höfler H, Slotta-Huspenina J and Becker KF: Activation of the PI3K/AKT pathway correlates with prognosis in stage II colon cancer. Br J Cancer 110: 2081-2089, 2014.

21. Sripa B, Leungwattanawanit S, Nitta T, Wongkham C, Bhudhisawasdi V, Puapairoj A, Sripa C and Miwa M: Establishment and characterization of an opisthorchiasis-associated cholangiocarcinoma cell line (KKU-100). World J Gastroenterol 11: 3392-3397, 2005.

22. Sun SY, Yue P, Dawson MI, Shroot B, Michel S, Lamph WW, Heyman RA, Teng M, Chandraratna RA, Shudo K, et al: Differential effects of synthetic nuclear retinoid receptor-selective retinoids on the growth of human non-small cell lung carcinoma cells. Cancer Res 57: 4931-4939, 1997.

23. Cantley LC: The phosphoinositide 3-kinase pathway. Science 296: 1655-1657, 2002.

24. Carnero A, Blanco-Aparicio C, Renner O, Link W and Leal JF: The PTEN/PI3K/AKT signalling pathway in cancer, therapeutic implications. Curr Cancer Drug Targets 8: 187-198, 2008. 
25. Chalhoub N and Baker SJ: PTEN and the PI3-kinase pathway in cancer. Annu Rev Pathol 4: 127-150, 2009.

26. Deng L, Chen J, Zhong XR, Luo T, Wang YP, Huang HF, Yin LJ, Qiu Y, Bu H, Lv Q and Zheng H: Correlation between activation of PI3K/AKT/mTOR pathway and prognosis of breast cancer in Chinese women. PLoS One 10: e0120511, 2015.

27. Ocana A, Vera-Badillo F, Al-Mubarak M, Templeton AJ, Corrales-Sanchez V, Diez-Gonzalez L, Cuenca-Lopez MD, Seruga B, Pandiella A and Amir E: Activation of the $\mathrm{PI} 3 \mathrm{~K} / \mathrm{mTOR} / \mathrm{AKT}$ pathway and survival in solid tumors: Systematic review and meta-analysis. PLoS One 9: e95219, 2014.

28. Shi J, Yao D, Liu W, Wang N, Lv H, Zhang G, Ji M, Xu L, He N, Shi B and Hou P: Highly frequent PIK3CA amplification is associated with poor prognosis in gastric cancer. BMC Cancer 12: $50,2012$.

29. Koul D, Fu J, Shen R, LaFortune TA, Wang S, Tiao N, Kim YW, Liu JL, Ramnarian D, Yuan Y, et al: Antitumor activity of NVP-BKM120-a selective pan class I PI3 kinase inhibitor showed differential forms of cell death based on p53 status of glioma cells. Clin Cancer Res 18: 184-195, 2012.

30. Hu Y, Guo R, Wei J, Zhou Y, Ji W, Liu J, Zhi X and Zhang J: Effects of PI3K inhibitor NVP-BKM120 on overcoming drug resistance and eliminating cancer stem cells in human breast cancer cells. Cell Death Dis 6: e2020, 2015.

31. Liang YC, Wu HG, Xue HJ, Liu Q, Shi LL, Liu T and Wu G: Effects of PI3K inhibitor NVP-BKM120 on acquired resistance to gefitinib of human lung adenocarcinoma H1975 cells. J Huazhong Univ Sci Technolog Med Sci 33: 845-851, 2013

32. Ayub A, Yip WK and Seow HF: Dual treatments targeting IGF-1R, PI3K, mTORC or MEK synergize to inhibit cell growth, induce apoptosis, and arrest cell cycle at G1 phase in MDA-MB-231 cell line. Biomed Pharmacother 75: 40-50, 2015.
33. Filbin MG, Dabral SK, Pazyra-Murphy MF, Ramkissoon S, Kung AL, Pak E, Chung J, Theisen MA, Sun Y, Franchetti Y, et al: Coordinate activation of $\mathrm{Shh}$ and PI3K signaling in PTEN-deficient glioblastoma: New therapeutic opportunities. Nat Med 19: 1518-1523, 2013.

34. Civallero M, Cosenza M, Pozzi S, Bari A, Ferri P and Sacchi S: Activity of BKM120 and BEZ235 against Lymphoma Cells. Biomed Res Int 2015: 870918, 2015.

35. Roper J, Sinnamon MJ, Coffee EM, Belmont P, Keung L, Georgeon-Richard L, Wang WV, Faber AC, Yun J, Yilmaz ÖH, et al: Combination PI3K/MEK inhibition promotes tumor apoptosis and regression in PIK3CA wild-type, KRAS mutant colorectal cancer. Cancer Lett 347: 204-211, 2014.

36. Pereira JK, Machado-Neto JA, Lopes MR, Morini BC, Traina F, Costa FF, Saad ST and Favaro P: Molecular effects of the phosphatidylinositol-3-kinase inhibitor NVP-BKM120 on T and B-cell acute lymphoblastic leukaemia. Eur J Cancer 51: 2076-2085, 2015

37. Park E, Park J, Han SW, Im SA, Kim TY, Oh DY and Bang YJ: NVP-BKM120, a novel PI3K inhibitor, shows synergism with a STAT3 inhibitor in human gastric cancer cells harboring KRAS mutations. Int J Oncol 40: 1259-1266, 2012.

38. Matas-Céspedes A, Rodriguez V, Kalko SG, Vidal-Crespo A Rosich L, Casserras T, Balsas P, Villamor N, Giné E, Campo E, et al: Disruption of follicular dendritic cells-follicular lymphoma cross-talk by the pan-PI3K inhibitor BKM120 ) Buparlisib). Clin Cancer Res 20: 3458-3471, 2014.

(i) $(-)$ This work is licensed under a Creative Commons Attribution-NonCommercial-NoDerivatives 4.0 International (CC BY-NC-ND 4.0) License. 